\author{
청보리 사일리지 TMR 또는 청호밀 사일리지 TME 급여 및 급여기간이 \\ 거세 한우의 증체, 사료비 및 육질특성에 미치는 효과 \\ 김광림 $^{1} \cdot$ 김종규 $^{1} \cdot$ 진위적 $^{1} \cdot$ 정 준 $^{2} \cdot$ 장선식 $^{3} \cdot$ 손용석 ${ }^{4} \cdot$ 최창원 $^{5} \cdot$ 송만강 $^{1 *}$ \\ ${ }^{1}$ 충북대학교 축산학과, ${ }^{2}$ 농협중앙회 축산연구원, ${ }^{3}$ 농촌진흥청 국립축산과학원, ${ }^{4}$ 고려대학교 생명과학대학, ${ }^{5}$ 대구대학교 동물자원학과
}

\title{
Effect of Feeding Whole Crop Barley Silage- or Whole Crop Rye Silage based-TMR and Duration of TMR Feeding on Growth, Feed Cost and Meat Characteristics of Hanwoo Steers
}

\author{
Guang Lin Jin ${ }^{1}$, Jong Kyu Kim ${ }^{1}$, Wei-ze Qin ${ }^{1}$, Jun Jeong ${ }^{2}$, Sun Sik Jang ${ }^{3}$, Yong Suk Sohn ${ }^{4}$, Chang Won Choi ${ }^{5}$ \\ and Man Kang Song ${ }^{1} *$ \\ ${ }^{1}$ Department of Animal Science, Chungbuk National University, Korea, ${ }^{2}$ Livestock Research Center, Agricultural Cooperative \\ Federation, Korea, ${ }^{3}$ National Institute of Animal Science, R.D.A., Korea, ${ }^{4}$ College of Biotechnology, Korea University, Seoul, \\ Korea, ${ }^{5}$ Department of Animal Resources, Daegu University, Korea
}

\begin{abstract}
Feeding trial was conducted with 80 Hanwoo steers (7.5 months of age, $204.4 \mathrm{~kg}$ body weight) for 680 days from growing period to late fattening period to examine the feeding value of whole crop barley silage TMR (BS-TMR) and whole crop rye silage TMR (RS-TMR) on body gain, feed cost, slaughter characteristics and quality characteristics of longissimus dorsi muscle. Dietary treatments were conventional separate feeding of concentrate and rice straw (control), feeding BS TMR up to middle fattening period and same diet as for control during late fattening period (BS-TMR I), feeding BS-TMR for whole experimental period (BS-TMR II), feeding RS TMR up to middle fattening period and same diet as for control during late fattening period (RS-TMR I) and RS TMR for whole experimental period (RS-TMR II). Sixteen castrated calves were assigned to each treatment ( 4 pens, 4 heads per pen). Pens in each treatment were randomly distributed. Feeding both BS silage TMR and RS silage TMR slightly increased body gain of Hanwoo steers at the stages of growing and early fattening, and increased $(\mathrm{P}<0.0001)$ at middle fattening compared to feeding control diet while control diet tended to increase body gain at late fattening stage compared to feeding BS-TMR I, BS-TMR II and RS-TMR I diets. Total body gain was slightly increased in Hanwoo steers fed both I and II for BS and RS TMR compared to that in control diet. Feed cost per $\mathrm{kg}$ gain per head was relatively low in the Hanwoo steers fed silage TMRs to that fed control diet. Carcass weight, back fat thickness and longissimus dorsi area of Hanwoo steers tended to increase but lowered $(\mathrm{P}<0.047)$ yield index by feeding silage TMRs. Feeding BS TMR slightly decreased marbling score but no difference was found in the number of head over grade 1 between diets. Control diet tended to improve yield grade compared to silage TMRs. Chemical composition, water holding capacity, drip loss, cooking loss and $\mathrm{pH}$, color and fatty acid composition of longissimus dorsi were not affected by experimental diets and feeding duration of silage TMRs. Shear force, however, was increased $(\mathrm{P}<0.046)$ by silage TMRs without difference between them compared to control diet. Based on the results of the current study, BS TMR and RS TMR could improve body gain and reduce feed cost without deteriorating meat quality compared to separate feeding of concentrate and rice straw. Overall feeding value was similar between BS TMR and RS TMR.
\end{abstract}

(Key words : Hanwoo steers, Silage TMR, Body gain, Feed cost, Carcass characteristics)

\begin{abstract}
서 론
반추동물에서의 조사료는 반추위의 정상적인 발달에 필수적인 사 료자원이며 조사료 자원의 품질은 생산성에도 크게 영향하는 것으

로 알려져 왔다(맹 등, 1989). 그러한 이유로 일찍이 국내에서도 젖소를 대상으로 하는 완전 혼합사료 (total mixed ration, TMR) 가 널리 활용되어 왔지만 한우에 $\mathrm{TMR}$ 을 도입하기 위한 본격적인 연구는 2000년대에 들어서야 이루어지기 시작했다.
\end{abstract}

* Corresponding author: Man Kang Song, Department of Animal Science, Chungbuk National University, Cheong-ju, Chungbuk 361-763, Korea. Tel: 043-261-2545, Fax: 043-274-2270, E-mail: mksong@cbnu.ac.kr 
김 등 (2003) 및 이 등(2003)은 건초 중심의 섬유질 배합사료가 반추위 내 발효성상과 소화율 및 비육 후기 거세한우의 성장에 미 치는 효과를 조사한 바 있다. 또한 조 등 (2008)은 거세한우를 대 상으로 한 섬유질 배합사료 급여가 증체, 도체특성 및 생산비에 미 치는 효과를 조사한 바, 배합사료와 볏짚을 중심으로 한 관행 사양 방법에 대한 비교 우위의 가능성을 제시한 바 있다. 뿐만 아니라, 거세 한우(조 등, 2000)는 물론 면양(이 등, 2002)과 흑염소(황 등, 2008)를 대상으로 각각 청예사료작물과 청보리 사일리지의 사 료적 가치가 조사한 결과 사료 이용성 측면에서 긍정적인 결과가 있었음이 발표되기도 했다.

근래에 들어 국제 곡물가격의 지속적인 상승으로 인하여 증가된 한우 생산비가 국내 부존자원의 적극적인 활용을 통한 한우산업 침 체의 돌파구를 마련하는 계기가 되었다. 특히, 청보리 및 청호밀 등 동계 사료작물을 한우 사료에 이용함으로서 원료사료의 수입으 로 인한 외화의 절약은 물론 유휴 농경지 활용 면적을 확대시켜 경 지 농가의 소득을 더 높이는 일거양득이 가능해졌다. 그러나 그동 안 동계 사료작물을 이용한 $\mathrm{TMR}$ 에 대한 연구가 대부분 청보리를 중심으로 이루어 졌으며, 청보리 사일리지 $\mathrm{TMR}$ 에 대한 시험기간 역시 일부 사양단계에 국한된 경우가 대부분이었다.

동계사료작물 각각에 대한 반추위 미생물에 의한 발효 특성과 분 해율 조사는 이용성 제고를 위한 필수적인 과정이다. Shinekhuu 등 (2010)은 국내에서 생산된 청보리 사일리지 (whole crop barley silage, BS)와 청호밀 사일리지 (whole crop rye silage, RS)를 포 함한 다양한 종류의 사료작물 사일리지를 대상으로 반추위미생물에 의한 in vitro 발효 성상과 분해율 등을 조사하였으며, 지 등 (2010) 역시 BS와 RS는 물론 이탈리안라이그라스 사일리지 및 수 단그라스 사일리지에 대한 소 체내 이용율 및 가소화영양소 총량 (TDN)을 직접 산출하기도 하였다. 뿐만 아니라, Qin 등 (2010)은 $\mathrm{BS}$ 및 $\mathrm{RS}$ 을 이용한 거세한우 비육 중기용 $\mathrm{TMR}$ 의 소 체내 이용 성을 조사하고 그 결과를 배합사료와 볏짚을 급여한 결과와 비교함 으로서 주요 동계 사료작물의 사료적 가치를 확인하기에 이르렀다. 그러나 거세한우의 육성기에서 출하시에 이르는 전체 사양기간에 걸쳐 이들 주요 사료작물로 조제된 TMR의 이용성이 배합사료 및 볏짚 중심의 관행사료 이용성과 비교된 결과는 보고된 바 없다. 따 라서 본 시험은 $\mathrm{BS}$ 및 $\mathrm{RS}$ 를 이용하여 조제한 $\mathrm{TMR}$ 급여가 거세 한우의 증체와 도체 특성 그리고 사료비에 미치는 효과를 규명하고 아울러 배합사료 및 볏짚 중심의 관행사료 이용성과 비교하고자 실 시되었다.

\section{재료 및 방법}

\section{1. 시험 동물, 시험 설계, 시험사료 및 사양관리}

거세한우 송아지 (평균 7.5 개월령, $204.4 \mathrm{~kg} \pm 14.7 \mathrm{~kg}$ ) 총 80 두 를 대상으로 하여 4개 성장 단계 (육성기, 7.5 12개월령; 비육 전 기, 13 18개월령; 비육 중기, 19 24개월령; 및 비육 후기, 25 30
개월령)에 따른 시험사료를 조제하여 전북 고창에 위치한 시험농장 에서 2008년 10월부터 2010년 8월까지 총 680 일간 사양시험을 실시하였다. 시험사료는 급여형태 및 급여기간에 따라 다음과 같이 총 5 개 처리구로 하였다. 즉, 성장 단계별로 계획된 급여 프로그램 에 따라 전체 사양기간 동안 배합사료와 볏짚을 분리 급여하는 관 행사양구 (Control), BS TMR을 육성기에서 비육중기까지 자유채 식토록 하고 비육 후기에는 관행사양구와 동일한 사료를 급여하는 처리구 (BS-TMR I), BS TMR을 비육 후기까지 자유채식토록 하 는 처리구(BS-TMR II), RS TMR을 비육중기까지 자유채식토록 하고 비육 후기에는 관행사양구와 동일한 사료를 급여하는 처리구 (RS-TMR I), 그리고 RS TMR을 비육 후기까지 자유채식토록 하 는 처리구(RS-TMR II)로 구성하였다. 각 처리 당 거세된 송아지 16 두를 공시하였으며, 처리 당 거세한우 송아지를 4 두씩 4 개의 pen에 배치하였다. 또한 pen 내 평균 체중의 차이를 줄임으로서 서열로 인한 사료섭취량의 편중 현상을 줄이도록 처리별 4개 pen 중 각 pen에 연령과 체중을 고려하여 송아지를 배치하였다.

본 시험에서 관행사양구의 성장단계별 배합사료는 농협 김제 배 합사료공장에서 생산된 것을 이용하였으며, 동계사료작물(청보리 및 청호밀) 사일리지는 2008년 2010년간에 걸쳐 관행에 따라 매 년 5월 중순에 수확되어 사일리지로 가공된 것을 이용하였다. 관행 사양구 사료와 청보리 및 청호밀 사일리지를 이용한 $\mathrm{TMR}$ 은 본 연구에서 자체적으로 계획한 사료급여 프로그램 (한우사양표준, 2007; 한우컨설팅지침서, 2009)에 따라 시험농장의 TMR 공장에 서 조제되었는데, 이 때 모든 처리구의 거세 한우에서 육성기, 비 육 전기, 비육 중기 및 비육 후기의 평균 일당증체량이 각각 0.75 $\mathrm{kg}, 0.95 \mathrm{~kg}, 0.88 \mathrm{~kg}$ 및 $0.72 \mathrm{~kg}$ 이 될 수 있도록 사료를 급여하였 다. 관행 사양구의 한우 육성기에는 볏짚을 두당 $2.0 \mathrm{~kg}$ (건물 기 준)을, 비육 전기와 비육 중기에는 1 일 두당 $1.5 \mathrm{~kg}$ (건물 기준) 급 여하였으며, 비육 후기에는 1 일 두당 $1.0 \mathrm{~kg}$ (건물 기준) 급여하였 다. 각 성장단계 및 처리별 시험사료의 배합비 및 영양소 함량은 Table 1 및 Table 2에서와 같다. 그러나 관행사양구의 한우에 급 여한 배합사료의 배합비는 조제공장 사정으로 제공받지 못했다. 볏 짚의 건물 (dry matter, $\mathrm{DM}$ ), 가소화영양소총량 (total digestible nutrient, $\mathrm{TDN}$ ), 조단백질 (crude protein, $\mathrm{CP}$ ), 조지방 (ether extract, $\mathrm{EE}$ ), 중성세제 불용성 섬유소(neutral detergent fiber, $\mathrm{NDF}$ ) 및 조회분 함량은 각각 $85.5 \%, 43,66 \%, 4.13 \%, 1.16 \%$, $70.25 \%$, 및 $11.23 \%$ 였다 (건물 기준). 시험사료는 관행사양구의 경 우 오전 8 시와 오후 5 시에 1 일 사료급여량을 동일한 양으로 2 회로 나누어 급여하였으며 TMR 급여구의 소에는 매일 섭취량을 조사한 후 1 일 1 회 예상섭취량보다 $5 \%$ 초과토록 급여하여 자유채식토록 하였다. 전체 처리구에 걸쳐 물과 린칼부록(주, 대한유팜)은 자유 로이 섭취토록 하였다.

\section{2. 조사 항목 및 시료 분석}

청보리 또는 청호밀 사일리지 $\mathrm{TMR}$ 과 관행사양구에서 사용한 
Table 1. Formulae (\%, as-fed basis) and chemical composition (\%, DM basis) of the experimental diets for the Hanwoo steers in growing period and early fattening period

\begin{tabular}{|c|c|c|c|c|c|c|}
\hline \multirow[t]{2}{*}{ Feed ingredients } & \multicolumn{3}{|c|}{$\begin{array}{l}\text { Growing period }{ }^{1)} \\
\text { (7.5 12 month of age) }\end{array}$} & \multicolumn{3}{|c|}{$\begin{array}{l}\text { Early fattening period } \\
(13 \sim 18 \text { month of age })\end{array}$} \\
\hline & Control & BS-TMR & RS-TMR & Control & BS-TMR & RS-TMR \\
\hline Basal feed $^{2)}$ & & 26.67 & 26.67 & & 10.00 & 10.00 \\
\hline Corn, ground & & - & & & 20.30 & 20.30 \\
\hline Wheat bran & & 7.00 & 7.00 & & - & - \\
\hline Corn gluten feed & & - & - & & 7.50 & 8.00 \\
\hline Corn cop pellet & & 18.87 & 18.87 & & 15.00 & 16.00 \\
\hline Brewers grain & & 3.00 & 3.00 & & 6.50 & 5.00 \\
\hline Whole cotton seed & & - & - & & 2.00 & 2.00 \\
\hline Molasses & & 3.00 & 3.00 & & 6.00 & 6.00 \\
\hline Whole crop barley silage & & 40.00 & - & & 30.00 & - \\
\hline Whole crop rye silage & & - & 40.00 & & - & 30.00 \\
\hline Limestone & & 0.93 & 0.93 & & 0.50 & 0.50 \\
\hline Salt & & 0.40 & 0.40 & & 0.20 & 0.20 \\
\hline Vitamin-mineral mix. ${ }^{3)}$ & & 0.13 & 0.13 & & 2.00 & 2.00 \\
\hline \multicolumn{7}{|c|}{ Chemical composition (\%, DM basis $)^{4)}$ : } \\
\hline Moisture & 11.30 & 36.28 & 35.29 & 11.33 & 34.43 & 36.46 \\
\hline Crude protein & 10.93 & 11.10 & 11.53 & 10.95 & 11.23 & 11.27 \\
\hline Ether extract & 3.61 & 4.81 & 4.40 & 6.35 & 5.38 & 5.35 \\
\hline Neutral detergent fiber & 39.00 & 50.77 & 53.42 & 36.73 & 48.77 & 44.78 \\
\hline Crude ash & 7.73 & 12.36 & 11.67 & 7.27 & 13.68 & 14.96 \\
\hline $\mathrm{TDN}^{5)}$ & 64.17 & 65.78 & 67.96 & 65.94 & 68.39 & 69.52 \\
\hline
\end{tabular}

${ }^{1)}$ Control, concentrate for the conventional feeding but its formula was not supplied from the feed mill company. Chemical compositions were sum of both concentrate (75\%) and rice straw (25) for growing period, and concentrate (80\%) and rice straw (20\%) for early fattening period. Chemical composition of rice straw was calculated based on Korean Feeding Standard for Hanwoo (2007) ; BS-TMR, whole crop barley based TMR; RS-TMR, whole crop rye based TMR.

${ }^{2)}$ Basal feed, mixed feed of $40 \%$ corn, $20 \%$ perilla oil meal, $20 \%$ distillers dried grains and 20\% wheat bran (as fed basis)

${ }^{3)}$ Vitamin-mineral additives, consisting of vitamin A, 8,000,000 IU/kg, vitamin D3, 600,000 IU/kg, vitamin E, 20,000 IU/kg, Mn, 100 $\mathrm{mg} / \mathrm{kg}$.

4) Analyzed values. ${ }^{5)}$ Calculated values.

배합사료 및 볏짚은 성장단계별로 시험 개시 전 및 그 후 2개월 간격으로 채취하여 일반 성분은 $\mathrm{AOAC}(1995)$ 방법에 준하여, 그 리고 NDF 함량은 Van Soest 등(1991)의 방법에 준하여 분석하 였다. 체중은 시험 개시 직전과 개시 후 종료될 때까지 1 개월 간격 으로 측정하였으며, 관행사양구의 볏짚을 포함한 모든 처리구의 사 료 섭취량은 아침 사료 급여 전 잔량을 수거하여 조사되었다.

도체등급은 도축 후 냉각실에서 $18 \sim 20^{\circ} \mathrm{C}$ 에서 예냉된 도체의 13 번째 갈비부위 절개면에서 축산물 품질관리원의 등급판정 기준에 따라 조사되었다. 또한 한우고기 시료(배최장근)의 일반성분은 $\mathrm{AOAC}$ (1995) 방법에 준하여 분석하였다. 먼저, 시료를 믹서기로 고르게 분쇄한 다음 잘 혼합한 후 그 일부를 냉동 건조하여 수분
함량을 조사하였다. 지방 함량은 soxhlet 방법으로 조사하였으며 단백질은 Kjeltec System(Kjeltec Auto 2400/2460, Foss Tecator $\mathrm{AB}$, Höganas, Sweden)을 이용하여 분석하였고, 회분은 회분분석기 (MAS 7000, CEM Corp., Matthews, NC, USA)를 이용하여 측정하였다.

믹서기로 고르게 분쇄된 한우 거세우의 배최장근 내 지방산 조성 을 조사하기 위해 일부를 Folch 등 (1957)의 방법에 따라 chloroform/methanol $(2: 1, \mathrm{v} / \mathrm{v})$ 에 넣은 다음 균질기 (homogenizer, PT-MR3100, Switzerland)를 이용하여 지방을 추출하였다. 추출된 지방이 포함된 chloroform을 질소 gas 주입하에 $50^{\circ} \mathrm{C}$ 의 Dri-Bath (Typel 6500, USA)에서 chloroform을 증발시켰다. 지방의 
Table 2. Formulae (\%, as-fed basis) and chemical composition (\%, DM basis) of the experimental diets for the Hanwoo steers in middle fattening period and late fattening period

\begin{tabular}{|c|c|c|c|c|c|c|}
\hline \multirow{2}{*}{ Feed ingredients } & \multicolumn{3}{|c|}{$\begin{array}{l}\text { Middle fattening period }{ }^{1)} \\
(19 \sim 24 \text { month of age })\end{array}$} & \multicolumn{3}{|c|}{$\begin{array}{l}\text { Late fattening period } \\
(25 \sim 30 \text { month of age })\end{array}$} \\
\hline & Control & BS-TMR & RS-TMR & Control & BS-TMR & RS-TMR \\
\hline Basal feed ${ }^{2)}$ & & 10.00 & 10.00 & & 10.00 & 10.00 \\
\hline Corn, ground & & 29.00 & 29.00 & & 35.40 & 35.40 \\
\hline Corn gluten feed & & 3.30 & 3.30 & & 14.50 & 14.50 \\
\hline Corn cop pellet & & 14.00 & 14.00 & & 15.00 & 15.00 \\
\hline Brewers grain & & 15.00 & 15.00 & & 5.00 & 5.00 \\
\hline Whole Cotton seed & & - & - & & 3.00 & 3.00 \\
\hline Molasses & & 6.00 & 6.00 & & 6.00 & 6.00 \\
\hline Whole crop barley silage & & 20.00 & - & & 10.00 & - \\
\hline Whole crop rye silage & & - & 20.00 & & - & 10.00 \\
\hline Limestone & & 0.50 & 0.50 & & 0.40 & 0.40 \\
\hline Salt & & 0.20 & 0.20 & & 0.20 & 0.20 \\
\hline Vitamin-mineral mix. ${ }^{3)}$ & & 2.00 & 2.00 & & 0.50 & 0.50 \\
\hline \multicolumn{7}{|l|}{ Chemical composition $^{4)}$ : } \\
\hline Moisture & 11.53 & 33.94 & 36.15 & 11.32 & 37.34 & 35.91 \\
\hline Crude protein & 10.43 & 10.38 & 10.47 & 10.65 & 10.79 & 10.85 \\
\hline Ether extract & 8.80 & 8.61 & 8.81 & 5.96 & 8.56 & 8.36 \\
\hline Neutral detergent fiber & 34.79 & 42.53 & 40.93 & 32.15 & 38.20 & 37.73 \\
\hline Crude ash & 6.13 & 5.61 & 7.62 & 6.36 & 6.43 & 6.89 \\
\hline $\mathrm{TDN}^{5)}$ & 67.75 & 70.56 & 71.04 & 70.07 & 71.51 & 71.85 \\
\hline
\end{tabular}

${ }^{1)}$ Control, Concentrate for the conventional feeding but its formula was not supplied from the feed mill company. Chemical compositions were sum of both concentrate $(85 \%)$ and rice straw $(15 \%)$ for middle fattening period, and concentrate $(90 \%)$ and rice straw $(10 \%)$ for late fattening period; Chemical composition of rice straw was calculated based on Korean Feeding Standard for Hanwoo (2007). BS-TMR, whole crop barley based TMR; RS-TMR, whole crop rye based TMR. estimation.

${ }^{2)}$ Basal feed, mixed feed of $40 \%$ corn, $20 \%$ perilla oil meal, distillers dried grains and $20 \%$ wheat bran (as fed basis)

${ }^{3)}$ Vitamin-mineral additives, consisting of vitamin A, 8,000,000 IU/kg, vitamin D3, 600,000 IU/kg, vitamin E, 20,000 IU/kg, Mn, $100 \mathrm{mg}$ $/ \mathrm{kg}$.

${ }^{4)}$ Analyzed values. ${ }^{5)}$ Calculated values.

methylation은 Lepage and Roy(1986)의 방법에 따라 실시되었 으며, $1 \mathrm{~mm}$ 를 취하여 $\mathrm{GC}$ 용 vial에 옮긴 다음 $\mathrm{GC}$ (Agilent $6890 \mathrm{~N}$ Agilent Co.)를 이용하여 지방산을 분석하였다. 이 때 fused silica capillary column $(100 \mathrm{~m} 0.25 \mathrm{~mm}$, i.d. $0.20 \mathrm{~mm}$ thickness, Supelco, $\mathrm{SP}^{\mathrm{TM}}-2560$, USA)을 사용하였으며, injector 와 detector 온도를 모두 $250^{\circ} \mathrm{C}$ 로 유지시켰다. 그리고 initial column 온도를 $175^{\circ} \mathrm{C}$ 로 하여 30 분간 유지시켰고, 그 후 분 당 $15^{\circ} \mathrm{C}$ 가 증가되도록 하였으며, 최종 $220^{\circ} \mathrm{C}$ 에서 40 분간 유지되도록 하였다. 지방산 분석을 위해 carrier gas로 ultra pure helium를 사 용하였으며, 지방산 standard (Sigma Chemical Co.)로 각각의 지 방산을 식별하였다.

한우 도체 (배최장근)의 이화학적 특성은 처리별로 도축된 한우의 배최장근을 취하여 조사항목별로 분석하였다. 먼저, 보수력 (water holding capacity)은 원심분리법을 이용하였는데, 분쇄된 시료 0.5 $\pm 0.05 \mathrm{~g}$ 을 원심분리관의 상부 filter 관에 넣은 다음 $80^{\circ} \mathrm{C}$ water-bath에 넣고 20 분간 가열한 후 10 분간 방냉시켰다. 그 후 상부 filter관을 원심분리관 하부에 넣고 $2000 \mathrm{rpm}$ 에서 10 분간 원 심분리하였다. 원심분리 후 남은 시료를 가열 전 시료무게 비율로 표시하였다.

육즙손실 (drip loss)은 $2 \mathrm{~cm}$ 두께의 우육 슬라이스를 원형 (중량 $100 \pm 5 \mathrm{~g}$ )으로 정형한 후 polypropylene bag에 넣고 진공포장하 여 $4^{\circ} \mathrm{C}$ 냉장고에서 24 시간 보관하면서 발생된 드립 감량을 측정하 여 초기시료의 무게비율 $(\%)$ 로 측정하였다.

가열감량은 $3 \mathrm{~cm}$ 두께의 우육 슬라이스를 원형 (중량 $150 \pm 5 \mathrm{~g}$ ) 으로 정형한 후 polypropylene bag에 넣고 진공포장하여 $70^{\circ} \mathrm{C}$ water-bath에서 40 분간 가열한 후 30 분간 방냉시킨 다음, 가열 후 
감량된 무게를 초기시료의 무게비율 $(\%)$ 로 측정하였다. 전단력 (Shear force test)은 Wheeler 등 (2000)의 방법에 따라 시료를 70 ${ }^{\circ} \mathrm{C}$ water-bath에 넣고 40 분간 가열한 후 30 분간 방냉시킨 다음 시 료를 가로 $\times$ 세로 $\times$ 높이를 각각 $1 \times 2 \times 1 \mathrm{~cm}$ 가 되도록 절단하여 Rheo meter (Model Compac-100, SUN SCIENTIFIC Co. LTD.)의 Shearing, Cutting Test로 Max weight를 측정하였는데, 이때 프로그램은 R.D.S (Rheology Data System) Ver 2.01을 이 용하였다. Table Speed는 $110 \mathrm{~mm} / \mathrm{min}$, Graph Interval은 20 $\mathrm{msec}$, Load cell $(\max )$ 는 $10 \mathrm{~kg}$ 의 조건으로 하였다.

한우고기 (배최장근)의 $\mathrm{pH}$ 는 $10 \mathrm{~g}$ 에 증류수 $100 \mathrm{ml}$ 을 가한 후 측 정하였다. 모든 시료는 균질기 (Bihon seiki, Ace, Japan)로 7,000 $\mathrm{rpm}$ 에서 30초간 균질시킨 후, $\mathrm{pH}$ meter (Mteeler Delta 340, Mettler-tolede, Ltd, UK)로 측정하였다. 한우고기 (배최장근)의 표 면육색은 백색판 $\left(\mathrm{L}^{*}, 89.39 ; \mathrm{a}^{*}, 0.13 ; \mathrm{b}^{*},-0.51\right)$ 으로 표준화시 킨 Spectro Colormeter (Model JX-777, Color Techno. System Co., japan)로 측정하였는데, 이때 광원은 백색형광등 (D65)을 사 용하여 Hunter $\mathrm{Lab}$ 표색계의 $\mathrm{L}^{*}, \mathrm{a}^{*}, \mathrm{~b}^{*}$ 값으로 나타냈다. $\left(\mathrm{L}^{*}=\right.$ 명도, $\mathrm{a}^{*=}$ 적색도, $\mathrm{b}^{*}=$ 황색도).

\section{3. 통계 분석}

본 연구에서 조사된 한우 수소의 사료 섭취 및 성장에 관련된 형질에 대한 성장 단계별 유의적 검정을 위하여 다음과 같은 통계 모형 식을 이용하였다.

$$
Y_{i j}=\mu+T_{i}+e_{i j}
$$

여기에서, $Y_{i j}$ 는 각 성장 단계별 초기 체중, 최종 체중, 증체량, 일일 증체량, 건물 섭취량, $\mathrm{TDN}$ 섭취량 및 사료 효율에 대한 측정 치 이며, $\mu$ 는 전체 평균이며, $T_{i}$ 는 $\mathrm{TMR}$ 기반의 사일리지 효과 (BS-TMR I, BS-TMR II, RS-TMR I, RS-TMR II)이며, $e$ 는 임 의 오차를 나타낸다. 위와 같이 설정된 통계 모형은 SAS 9.1 Package (2002)를 이용하여 분석하였으며, GLM (Generalized Linear Model) 분석을 통하여 각 효과들에 대한 분산 분석을 실시 하였다. 각 처리별 평균간 성적은 다중 비교 검증인 S-N-K(Steel 과 Torrie, 1980) 방법으로 비교하였다.

\section{결 과}

\section{1. 증체량, 사료섭취량 및 사료효율}

동계사료작물(청보리 및 청호밀) 사일리지 $\mathrm{TMR}$ 급여가 거세 한우의 증체 및 육질 특성에 미치는 효과를 조사하고 관행사양 방 법의 시험 결과와 비교하였다. 한우 거세우의 각 성장 단계별 증체 와 사료섭취량 및 사료효율은 Table 3에서 보는 바와 같다.

먼저, 평균 $204.4 \mathrm{~kg}$ 거세한우 송아지를 대상으로 138 일간에 걸
친 육성기 동안 총 증체량은 관행사양구인 대조구, 청보리 사일리 지 TMR I(BS-TMR I), 청보리 사일리지 TMR II (BS-TMR II), 청호밀 사일리지 TMR I RS-TMR I) 및 청호밀 사일리지 TMR II (RS-TMR II)에서 각각 $80.0,90.2,82.9,85.5$ 및 $85.0 \mathrm{~kg}$ 이었 으며, 평균 일당증체량은 각각 $0.58,0.65,0.60,0.61$ 및 $0.61 \mathrm{~kg}$ 으로 시험사료 간 차이를 보이지 않았다. 육성기간 동안 처리별 평 균 1 일 건물섭취량은 대조구, BS-TMR I, BS-TMR II, RSTMR I 및 RS-TMR II에서 각각 7.14, 6.97, 7.06, 7.64 및 7.44 $\mathrm{kg}$ 으로 처리간 유의적인 차이가 없었으며, 1 일 $\mathrm{TDN}$ 섭취량도 각 각 $4.52,4.58,4.64,5.19$ 및 $5.06 \mathrm{~kg}$ 으로 처리간 유의적인 차이 가 없었지만 TMR 급여구에 비해 대조구 한우의 TDN 섭취량이 다소 낮은 것으로 나타났다. 사료효율은 BS-TMR I 처리구를 제외 하면 다른 TMR 섭취구에 비하여 대조구에서 다소 높은 것으로 나타났으나 시험사료 간 차이는 없는 것으로 나타났다.

또한 182 일간에 걸친 비육전기 동안 총 증체량은 관행사양구인 대조구, BS-TMR I, BS-TMR II, RS-TMR I 및 RS-TMR II에 서 각각 $150.8,171.0,166.6,161.0$ 및 $167.8 \mathrm{~kg}$ 이었으며, 일당증 체량은 각각 $0.83,0.94,0.92,0.89$ 및 $0.93 \mathrm{~kg}$ 으로 시험사료 간 큰 차이는 없었지만 사일지리 TMR 급여구의 한우 거세우 대부분 의 증체량이 관행사양구인 대조구에 비해 다소 높은 경향을 보였 다. 비육전기 동안 처리별 평균 1 일 건물섭취량은 대조구, BSTMR I, BS-TMR II, RS-TMR I 및 RS-TMR II에서 각각 8.32, $9.50,9.44,9.63$ 및 $9.57 \mathrm{~kg}$ 으로 대조구에 비해 사일리지 TMR 급여구에서 높았으며 $(\mathrm{P}<0.04), 1$ 일 $\mathrm{TDN}$ 섭취량도 각각 5.54 , $6.50,6.46,6.69$ 및 $6.65 \mathrm{~kg}$ 으로 대조구에 비하여 사일리지 TMR 급여구의 한우에서 높았다 $(\mathrm{P}<0.038)$. 그러나 사료효율은 사일리지 급여구에서의 다소 높은 일당증체량으로 인하여 사료효율에서는 시 험사료 간 큰 차이가 없었다.

비육중기 (178일) 동안 총 증체량은 관행사양구인 대조구, BSTMR I, BS-TMR II, RS-TMR I 및 RS-TMR II에서 각각 $126.7,152.8,154.0,147.5$ 및 $146.0 \mathrm{~kg}$ 이었으며, 평균 일당증체 량은 각각 $0.72,0.86,0.86,0.83$ 및 $0.82 \mathrm{~kg}$ 으로 대조구에 비해 사일지리 TMR 급여구의 한우 거세우에서 총 증체량 $(\mathrm{P}<0.0001)$ 및 일당증체량 $(\mathrm{P}<0.0002)$ 이 더 증가된 것으로 조사되었다. 그러나 사일리지 TMR 급여구 간에는 차이가 없었다. 비육중기 동안 처리 별 평균 1 일 건물섭취량은 대조구, BS-TMR I, BS-TMR II, RS-TMR I 및 RS-TMR II에서 각각 9.18, 10.18, 10.14, 10.16 및 $10.19 \mathrm{~kg}$ 으로 대조구에 비해 TMR 급여구에서 높았으며 $(\mathrm{P}<$ $0.0001), 1$ 일 $\mathrm{TDN}$ 섭취량도 각각 $6.19,7.18,7.15,7.22$ 및 7.24 $\mathrm{kg}$ 으로 $\mathrm{TMR}$ 급여구에서의 높은 것으로 나타났다 $(\mathrm{P}<0.003)$. 그러 나 사료효율은 시험사료 간 차이가 없었으며 사일리지 TMR 급여 구 간에도 차이가 없는 것으로 나타났다.

비육후기 (182일) 동안 총 증체량은 관행사양구인 대조구, BSTMR I, BS-TMR II, RS-TMR I 및 RS-TMR II에서 각각 $122.3,115.2,111.0,110.0$ 및 $125.7 \mathrm{~kg}$ 이었으며, 평균 일당증체 량은 각각 $0.67,0.63,0.61,0.60$ 및 $0.69 \mathrm{~kg}$ 으로 대조구 및 
Table 3. Feed intake and growth of Hanwoo steers by growth stage as influenced by feeding the whole crop silage based TMR

\begin{tabular}{|c|c|c|c|c|c|c|c|c|}
\hline \multirow{2}{*}{$\begin{array}{l}\text { Growing } \\
\text { stage }\end{array}$} & \multirow{2}{*}{ Items } & \multicolumn{5}{|c|}{ Experimental diets ${ }^{1)}$} & \multirow{2}{*}{ SEM $^{2)}$} & \multirow{2}{*}{$\operatorname{Pr}>F^{3)}$} \\
\hline & & Control & BS-TMR I & BS-TMR II & RS-TMR I & RS-TMR II & & \\
\hline \multirow{7}{*}{$\begin{array}{l}\text { Growing period } \\
\text { ( } 7.5 \sim 12 \text { month } \\
\text { of age) }\end{array}$} & Initial B.W., kg & 201.5 & 201.3 & 206.8 & 211.8 & 200.5 & 14.894 & 0.979 \\
\hline & Final B.W., kg & 281.5 & 291.5 & 289.7 & 297.3 & 285.5 & 15.710 & 0.962 \\
\hline & Total gain, $\mathrm{kg}$ & 80.0 & 90.2 & 82.9 & 85.5 & 85.0 & 3.998 & 0.524 \\
\hline & Daily gain, $\mathrm{kg}$ & 0.58 & 0.65 & 0.60 & 0.61 & 0.61 & 0.029 & 0.509 \\
\hline & DM intake, $\mathrm{kg} / \mathrm{d}$ & 7.14 & 6.97 & 7.06 & 7.64 & 7.44 & 0.278 & 0.431 \\
\hline & TDN intake, $\mathrm{kg} / \mathrm{d}$ & 4.52 & 4.58 & 4.64 & 5.19 & 5.06 & 0.136 & 0.067 \\
\hline & Feed efficiency & 12.31 & 10.72 & 11.77 & 12.52 & 12.20 & 0.653 & 0.444 \\
\hline \multirow{7}{*}{$\begin{array}{c}\text { Early } \\
\text { fattening period } \\
(13 \sim 18 \text { month } \\
\text { of age })\end{array}$} & Initial B.W., kg & 281.5 & 291.5 & 289.7 & 297.3 & 285.5 & 15.710 & 0.962 \\
\hline & Final B.W., kg & 432.3 & 462.5 & 456.3 & 458.3 & 453.3 & 14.466 & 0.625 \\
\hline & Total gain, $\mathrm{kg}$ & 150.8 & 171.0 & 166.6 & 161.0 & 167.8 & 6.091 & 0.198 \\
\hline & Daily gain, $\mathrm{kg}$ & 0.83 & 0.94 & 0.92 & 0.89 & 0.93 & 0.034 & 0.225 \\
\hline & DM intake, $\mathrm{kg} / \mathrm{d}$ & $8.32^{\mathrm{b}}$ & $9.50^{\mathrm{a}}$ & $9.44^{\mathrm{a}}$ & $9.63^{\mathrm{a}}$ & $9.57^{\mathrm{a}}$ & 0.031 & 0.040 \\
\hline & TDN intake, $\mathrm{kg} / \mathrm{d}$ & $5.54^{\mathrm{b}}$ & $6.50^{\mathrm{a}}$ & $6.46^{\mathrm{a}}$ & $6.69^{\mathrm{a}}$ & $6.65^{\mathrm{a}}$ & 0.184 & 0.038 \\
\hline & Feed efficiency & 10.02 & 10.11 & 10.26 & 10.84 & 10.30 & 0.498 & 0.775 \\
\hline \multirow{7}{*}{$\begin{array}{c}\text { Middle } \\
\text { fattening period } \\
(19 \sim 24 \text { month } \\
\text { of age })\end{array}$} & Initial B.W., kg & 432.3 & 462.5 & 456.3 & 458.3 & 453.3 & 14.466 & 0.625 \\
\hline & Final B.W., kg & 559.0 & 615.3 & 610.3 & 605.8 & 599.3 & 15.928 & 0.146 \\
\hline & Total gain, $\mathrm{kg}$ & $126.7^{\mathrm{b}}$ & $152.8^{\mathrm{a}}$ & $154.0^{\mathrm{a}}$ & $147.5^{\mathrm{a}}$ & $146.0^{\mathrm{a}}$ & 3.168 & 0.0001 \\
\hline & Daily gain, $\mathrm{kg}$ & $0.72^{\mathrm{b}}$ & $0.86^{\mathrm{a}}$ & $0.86^{\mathrm{a}}$ & $0.83^{\mathrm{a}}$ & $0.82^{\mathrm{a}}$ & 0.018 & 0.0002 \\
\hline & DM intake, $\mathrm{kg} / \mathrm{d}$ & $9.18^{\mathrm{b}}$ & $10.18^{\mathrm{a}}$ & $10.14^{\mathrm{a}}$ & $10.16^{\mathrm{a}}$ & $10.19^{\mathrm{a}}$ & 0.027 & 0.0001 \\
\hline & TDN intake, $\mathrm{kg} / \mathrm{d}$ & $6.19^{\mathrm{b}}$ & $7.18^{\mathrm{a}}$ & $7.15^{\mathrm{a}}$ & $7.22^{\mathrm{a}}$ & $7.24^{\mathrm{a}}$ & 0.177 & 0.003 \\
\hline & Feed efficiency & 12.93 & 11.84 & 11.79 & 12.24 & 12.43 & 0.284 & 0.063 \\
\hline \multirow{7}{*}{$\begin{array}{l}\text { Late } \\
\text { fattening period } \\
(25 \sim 30 \text { month } \\
\text { of age })\end{array}$} & Initial B.W., kg & 559.0 & 615.3 & 610.3 & 605.8 & 599.3 & 15.928 & 0.146 \\
\hline & Final B.W., kg & 681.3 & 730.5 & 721.3 & 715.8 & 725.0 & 14.531 & 0.181 \\
\hline & Total gain, $\mathrm{kg}$ & 122.3 & 115.2 & 111.0 & 110.0 & 125.7 & 5.367 & 0.238 \\
\hline & Daily gain, $\mathrm{kg}$ & 0.67 & 0.63 & 0.61 & 0.60 & 0.69 & 0.029 & 0.229 \\
\hline & DM intake, $\mathrm{kg} / \mathrm{d}$ & $11.69^{\mathrm{a}}$ & $8.97^{\mathrm{c}}$ & $10.01^{\mathrm{b}}$ & $9.07^{\mathrm{c}}$ & $10.12^{\mathrm{b}}$ & 0.041 & 0.0001 \\
\hline & TDN intake, $\mathrm{kg} / \mathrm{d}$ & $8.24^{\mathrm{a}}$ & $6.26^{\mathrm{c}}$ & $7.16^{\mathrm{b}}$ & $6.33^{\mathrm{c}}$ & $7.27^{\mathrm{b}}$ & 0.211 & 0.039 \\
\hline & Feed efficiency & $17.44^{\mathrm{a}}$ & $14.23^{\mathrm{b}}$ & $16.41^{\mathrm{ab}}$ & $15.12^{\mathrm{ab}}$ & $14.67^{\mathrm{ab}}$ & 0.763 & 0.032 \\
\hline
\end{tabular}

${ }^{1)}$ Control, conventional separate feeding of concentrate and rice straw; BS-TMR, whole crop barley silage based TMR; RS-TMR, whole crop rye silage based TMR. The Hanwoo steers were fed BS-TMR I and RS-TMR I up to middle fattening stage, and were fed the diet same as control during late fattening stage.

2) Standard error of the means. ${ }^{3)}$ Probability level.

* 43.7\% of TDN value was used for the calculation of rice straw based on Korean Feeding Standard for Hanwoo (2007).

RS-TMR II구의 한우에서 다소 높은 경향을 보였다. 비육후기 동 다음으로 RS-TMR II, BS-TMR II 순으로 높았고 BS-TMR에서 안 처리별 평균 1 일 건물섭취량은 대조구, BS-TMR I, BS-TMR 가장 낮았다. 1 일 평균 TDN 섭취량은 각각 $8.24,6.26,7.16$, II, RS-TMR I 및 RS-TMR II에서 각각 $11.69,8.97,10.01,6.33$ 및 $7.27 \mathrm{~kg}$ 으로 대조구에서 가장 높았으며 비육 후기에 대조 9.07 및 $10.12 \mathrm{~kg}$ 으로 대조구에서 가장 높았으며 $(\mathrm{P}<0.0001)$, 그 구와 동일한 사료를 섭취한 BS-TMR I 및 RS-TMR I에서 낮았다 
$(\mathrm{P}<0.039)$. 그러나 대조구의 한우에서의 높은 건물섭취량에 비하여 처리간 큰 차이가 없었던 일당증체량으로 인하여 사료 효율은 가장 저조한 $(\mathrm{P}<0.032)$ 것으로 나타났다. 건물섭취량과 사료효율에서는 사일리지 TMR 급여구 간에 차이가 없었다. 본 시험 기간 중 1 개 월 간격으로 조사된 체중을 바탕으로 도출된 시험사료별 체중변화 를 보면 Fig. 1에서와 같다.

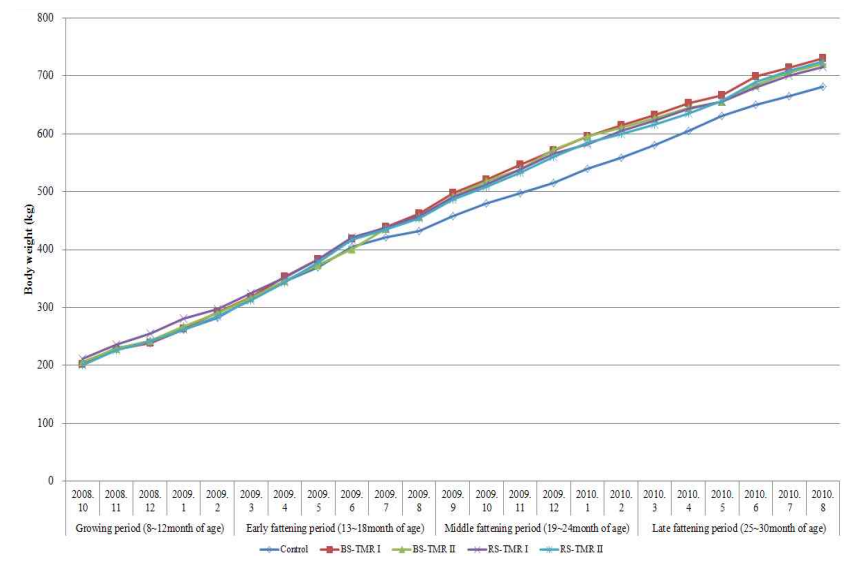

Fig. 1. Body weight change of Hanwoo steers by growth stage as influenced by feeding the whole crop silage based TMR.

\section{2. 사료비}

총 680 일간에 걸쳐 한우 거세우에서 섭취한 시험사료비를 성단 계별로 추정한 결과는 Table 4에서 보는 바와 같다. 먼저, 육성기 동안 급여한 처리구별 시험사료인 대조구, BS-TMR 및 RS-TMR 의 건물 $\mathrm{kg}$ 당 사료비는 각각 528,452 및 439원이었으며, 1 일 건물 섭취량으로 계산된 사료비는 대조구, BS-TMR I, BS-TMR II, RS-TMR I 및 RS-TMR II에서 각각 3,770, 3,150, 3,191, 3,353 및 3,266원으로 관행사료 급여구 (대조구)에서 다소 높았다. 육성기 동안 한우 거세우에 급여한 두당 사료비는 대조구, BS-TMR I, BS-TMR II, RS-TMR I 및 RS-TMR II에서 각각 $520,206,434,700,440,358,462,714$ 및 450,708원으로 추정되었 는 바, 이를 대조구 사료비에 비교할 경우 육성기간 동안 BSTMR I, BS-TMR II, RS-TMR I 및 RS-TMR II에서 각각 $85,506,79,848,57,492$ 및 69,498 원의 사료비가 적게 소요된 것 으로 나타났다. 또한 처리별 증체 $\mathrm{kg}$ 당 사료비를 비교하면 대조 구, BS-TMR I, BS-TMR II, RS-TMR I 및 RS-TMR II에서 각 각 $6,503,4,819,5,312,5,412$ 및 5,302원으로서 관행사료비에 비하여 사일리지 TMR 처리구에서 1000 원 이상 적게 소요된 것으 로 추정되었다.

비육전기 (182일) 동안 급여한 처리구별 시험사료인 대조구, $\mathrm{BS}-\mathrm{TMR}$ 및 RS-TMR의 건물 $\mathrm{kg}$ 당 사료비는 각각 452,458 및 447 원이었으며, 1 일 건물 섭취량으로 계산된 사료비는 대조구, BS-TMR I, BS-TMR II, RS-TMR I 및 RS-TMR II에서 각각
$3,761,4,351,4,324,4,305$ 및 4,278원으로 관행사료 급여구(대 조구)에 비하여 사일리지 TMR 섭취구에서 다소 높았다. 비육전기 동안 한우 거세우에 급여한 두당 사료비는 대조구, BS-TMR I, BS-TMR II, RS-TMR I 및 RS-TMR II에서 각각 684,502, $791,882,786,968,783,510$ 및 778,596원으로 추정되었는 바, 이 를 대조구 사료비에 비교할 경우 비육전기 동안 BS-TMR I, BS-TMR II, RS-TMR I 및 RS-TMR II에서 각각 107,380, $102,466,99,008$ 및 94,094원의 사료비가 더 소요된 것으로 나타 났다. 또한 처리별 증체 $\mathrm{kg}$ 당 사료비를 비교하면 대조구, BS-TMR I, BS-TMR II, RS-TMR I 및 RS-TMR II에서 각각 $4,545,4,636,4,727,4,864$ 및 4,637원으로서 관행사료비 (대조구) 에 비하여 사일리지 TMR 처리별로 100 원 300 원 정도 더 많이 소요된 것으로 추정되었다.

비육중기 (178일) 동안 급여한 처리구별 시험사료인 대조구, $\mathrm{BS}-\mathrm{TMR}$ 및 RS-TMR의 건물 $\mathrm{kg}$ 당 사료비는 각각 450,451 및 460 원 이었으며, 1 일 건물 섭취량으로 계산된 사료비는 대조구, BS-TMR I, BS-TMR II, RS-TMR I 및 RS-TMR II에서 각각 $4,131,4,592,4,573,4,674$ 및 4,687원으로 비육전기에서와 같이 관행사료 급여구(대조구)에 비하여 사일리지 TMR 섭취구에서 다 소 높았다. 비육중기 동안 한우 거세우에 급여한 두당 사료비는 대 조구, BS-TMR I, BS-TMR II, RS-TMR I 및 RS-TMR II에서 각각 $775,318,817,376,813,994,831,972$ 및 834,286원으로 추 정되었는 바, 이를 대조구 사료비에 비교할 경우 비육중기 동안 BS-TMR I, BS-TMR II, RS-TMR I 및 RS-TMR II에서 각각 $82,058,78,676,96,654$ 및 98,968원의 사료비가 더 소요된 것으 로 나타났다. 그러나 처리별 증체 $\mathrm{kg}$ 당 사료비를 비교하면 대조 구, BS-TMR I, BS-TMR II, RS-TMR I 및 RS-TMR II에서 각 각 $5,794,5,346,5,296,5,656$ 및 5,718원으로서 관행사료비 (대 조구)에 비하여 사일리지 TMR 급여구에서 다소 적게 소요되었다.

비육후기 (182일) 동안 급여한 처리구별 시험사료에서 대조구, BS-TMR I 및 RS-TMR I의 경우 3처리 모두 대조구와 동일한 사료를 사용하여 건물 $\mathrm{kg}$ 당 사료비는 444원이었으며, BS-TMR II과 RS-TMR II의 사료비는 각각 492 및 481원이었다. 또한 1 일 건물 섭취량으로 계산된 사료비는 대조구, BS-TMR I, BS-TMR I, RS-TMR I 및 RS-TMR II에서 각각 5,190, 3,983, 4,925, 4,027 및 4,868원으로 육성기에서와 같이 관행사료 급여구(대조 구)에 비하여 사일리지 TMR 섭취구에서 다소 낮았다. 비육후기 동안 한우 거세우에 급여한 두당 사료비는 대조구, BS-TMR I, BS-TMR II, RS-TMR I 및 RS-TMR II에서 각각 944,580, $724,906,896,350,732,914$ 및 885,976원으로 추정되었는 바, 이 를 대조구 사료비에 비교할 경우 비육후기 동안 BS-TMR I, BS-TMR II, RS-TMR I 및 RS-TMR II에서 각각 219,674, $48,230,211,666$ 및 58,604원의 사료비가 더 적게 소요된 것으로 나타났다. 또한 처리별 증체 $\mathrm{kg}$ 당 사료비를 비교하면 대조구, BS-TMR I, BS-TMR II, RS-TMR I 및 RS-TMR II에서 각각 $7,736,6,426,8,208,6,805$ 및 7,215원으로서 관행사료비 (대조구) 
Table 4. Feed cost for Hanwoo steers by growth stage by growth stage as influenced by feeding the whole crop silage based TMR

\begin{tabular}{|c|c|c|c|c|c|c|}
\hline \multirow{2}{*}{$\begin{array}{l}\text { Growing } \\
\text { stage }\end{array}$} & \multirow{2}{*}{ Items } & \multicolumn{5}{|c|}{ Experimental diets ${ }^{1)}$} \\
\hline & & Control & BS-TMR I & BS-TMR II & RS-TMR I & RS-TMR II \\
\hline \multirow{6}{*}{$\begin{array}{c}\text { Growing } \\
\text { period }\end{array}$} & Feed $\operatorname{cost}^{2}$, won/kg DM & 528 & 452 & 452 & 439 & 439 \\
\hline & Feed cost, won/DM intake/day & 3,770 & 3,150 & 3,191 & 3,353 & 3,266 \\
\hline & Feed cost, won/138days & 520,206 & 434,700 & 440,358 & 462,714 & 450,708 \\
\hline & Feed cost relative to control, (won/head) & 0 & $-85,506$ & $-79,848$ & $-57,492$ & $-69,498$ \\
\hline & Total body gain, $\mathrm{kg}$ & 80.0 & 90.2 & 82.9 & 85.5 & 85.0 \\
\hline & Feed cost, won $/ \mathrm{kg}$ body gain & 6,503 & 4,819 & 5,312 & 5,412 & 5,302 \\
\hline \multirow{6}{*}{$\begin{array}{c}\text { Early } \\
\text { fattening } \\
\text { period }\end{array}$} & Feed $\operatorname{cost}^{2}{ }^{2}$, won $/ \mathrm{kg} \mathrm{DM}$ & 452 & 458 & 458 & 447 & 447 \\
\hline & Feed cost, won/DM intake/day & 3,761 & 4,351 & 4,324 & 4,305 & 4,278 \\
\hline & Feed cost, won/182days & 684,502 & 791,882 & 786,968 & 783,510 & 778,596 \\
\hline & Feed cost relative to control, (won/head) & 0 & $+107,380$ & $+102,466$ & $+99,008$ & $+94,094$ \\
\hline & Total body gain, $\mathrm{kg}$ & 150.6 & 170.8 & 166.5 & 161.1 & 167.9 \\
\hline & Feed cost, won $/ \mathrm{kg}$ body gain & 4,545 & 4,636 & 4,727 & 4,864 & 4,637 \\
\hline \multirow{6}{*}{$\begin{array}{l}\text { Middle } \\
\text { fattening } \\
\text { period }\end{array}$} & Feed $\operatorname{cost}^{2}$, won $/ \mathrm{kg} \mathrm{DM}$ & 450 & 451 & 451 & 460 & 460 \\
\hline & Feed cost, won/DM intake/day & 4,131 & 4,592 & 4,573 & 4,674 & 4,687 \\
\hline & Feed cost, won/178days & 775,318 & 817,376 & 813,994 & 831,972 & 834,286 \\
\hline & Feed cost relative to control, (won/head) & 0 & $+82,058$ & $+78,676$ & $+96,654$ & $+98,968$ \\
\hline & Total body gain, $\mathrm{kg}$ & 126.9 & 152.9 & 153.8 & 147.1 & 145.9 \\
\hline & Feed cost, won/kg body gain & 5,794 & 5,346 & 5,296 & 5,656 & 5,718 \\
\hline \multirow{6}{*}{$\begin{array}{c}\text { Late } \\
\text { fattening } \\
\text { period }\end{array}$} & Feed $\operatorname{cost}^{2}$, won $/ \mathrm{kg} \mathrm{DM}$ & 444 & 444 & 492 & 444 & 481 \\
\hline & Feed cost, won/DM intake/day & 5,190 & 3,983 & 4,925 & 4,027 & 4,868 \\
\hline & Feed cost, won/182days & 944,580 & 724,906 & 896,350 & 732,914 & 885,976 \\
\hline & Feed cost relative to control, (won/head) & 0 & $-219,674$ & $-48,230$ & $-211,666$ & $-58,604$ \\
\hline & Total body gain, $\mathrm{kg}$ & 122.1 & 112.8 & 109.2 & 107.7 & 122.8 \\
\hline & Feed cost, won $/ \mathrm{kg}$ body gain & 7,736 & 6,426 & 8,208 & 6,805 & 7,215 \\
\hline
\end{tabular}

${ }^{1)}$ Control, conventional separate feeding of concentrate and rice straw; BS-TMR, whole crop barley silage based TMR; RS-TMR, whole crop rye silage based TMR. The Hanwoo steers were fed BS-TMR I and RS-TMR I up to middle fattening stage, and were fed the diet same as control during late fattening stage.

2) The price of concentrate was suggested by Gochang-buan livestock corporation as manufactured by Kimjae feed mill company(won/kg $\mathrm{DM}$ ), and the prices of TMR was suggested by Gochang-buan livestock corporation for the members(won $/ \mathrm{kg}$, DM).

에 비하여 BS-TMR II 처리구에서 다소 높게 소요되었지만 다른 $\mathrm{TMR}$ 처리구에서는 다소 적게 소요된 것으로 나타났다.

한우 거세우를 대상으로 실시한 전체 사양시험 기간(680일) 동 안의 시험사료 급여에 따른 증체와 사료섭취량, 그리고 사료비를 종합하면 Table 5에서 보는 바와 같다. 시험 개시 시 처리 간 평 균 체중에서 차이가 크지 않았으나, 종료 시 체중은 대조구보다 $\mathrm{TMR}$ 급여구에서 더 큰 경향을 보였다. 총 증체량의 경우 관행사 양구(대조구)의 $479.8 \mathrm{~kg}$ 에 비해 $\mathrm{TMR}$ 급여구에서 현저히 $(\mathrm{P}<0.047)$ 개선되었는데, BS-TMR I, BS-TMR II, RS-TMR I 및 RS-TMR II에서 각각 평균 49.4, 34.7, 24.2 및 $44.7 \mathrm{~kg}$ 이 더
증체된 것으로 조사되었다. 이에 따라 평균 일당증체량 역시 사일 리지 TMR 섭취구의 사료에서 높았다 $(\mathrm{P}<0.047)$. 평균 1 일 건물 섭취량은 대조구, BS-TMR II 및 RS-TMR I 처리구 간에는 차이 가 없었으나 대조구에 비해 BS-TMR I 처리구에서 다소 적은 반 면 RS-TMR II 처리구에서 다소 높은 것으로 나타났다.

총 사양기간 동안의 각 처리별 사료비 총액에서는 관행사양구(대 조구)에 비해 비육 중기까지 사일리지 TMR을 섭취하고 비육 후기 에는 관행사양구와 동일한 사료를 섭취한 BS-TMR I 및 RS-TMR I 처리구에서 다소 적게 소요된 반면 비육 후기까지 사일리지 $\mathrm{TMR}$ 을 섭취한 처리구(BS-TMR II 및 RS-TMR II)에서는 다소 
더 많이 소요된 것으로 추정되었다. 두 종류의 사일리지 TMR 섭 취로 인하여 증가된 증체량과 처리 간 비슷한 총 사료비로 인하여 전체 사양기간에서 두당 $\mathrm{kg}$ 증체에 소요된 사료비는 대조구의 6,033원에 비하여 BS-TMR I, BS-TMR II, RS-TMR I 및 $\mathrm{RS}-\mathrm{TMR}$ II에서 각각 평균 $801,324,456$ 및 410원이 더 적게 소요된 것으로 계산되었다.

\section{3. 도체 특성}

본 사양시험이 종료된 후 도축장에서 계측된 절식체중, 냉도체중, 등지방 특성과 육질 및 육량 특성이 조사된 바 Table 6에서와 같 다. 절식 체중의 경우 관행사양구 (대조구)에 비해 사일리지 TMR 을 섭취한 한우 거세우의 절식 평균 체중이 현저히 $(\mathrm{P}<0.0006)$ 큰

Table 5. Overall estimation in performance of Hanwoo steers and feed cost as influenced by feeding the whole crop silage based TMR

\begin{tabular}{|c|c|c|c|c|c|c|c|}
\hline \multirow{2}{*}{ Items } & \multicolumn{5}{|c|}{ Experimental diets ${ }^{1)}$} & \multirow{2}{*}{$\mathrm{SEM}^{2)}$} & \multirow{2}{*}{$\operatorname{Pr}>F^{3)}$} \\
\hline & Control & BS-TMR I & BS-TMR II & RS-TMR I & RS-TMR II & & \\
\hline Initial B.W., kg & 201.5 & 201.3 & 206.8 & 211.8 & 200.5 & 14.894 & 0.979 \\
\hline Final B.W., kg & 681.3 & 730.5 & 721.3 & 715.8 & 725.0 & 14.541 & 0.181 \\
\hline Total gain, $\mathrm{kg}$ & $479.8^{\mathrm{b}}$ & $529.2^{\mathrm{a}}$ & $514.5^{\mathrm{a}}$ & $504.0^{\mathrm{ab}}$ & $524.5^{\mathrm{a}}$ & 9.476 & 0.047 \\
\hline Daily gain, $\mathrm{kg}$ & $0.705^{\mathrm{b}}$ & $0.778^{\mathrm{a}}$ & $0.756^{\mathrm{a}}$ & $0.741^{\mathrm{ab}}$ & $0.771^{\mathrm{a}}$ & 0.021 & 0.047 \\
\hline DM intake, $\mathrm{kg} / \mathrm{d}$ & 9.21 & 9.02 & 9.29 & 9.22 & 9.45 & 0.238 & 0.317 \\
\hline Feed efficiency & 13.06 & 11.59 & 12.29 & 12.44 & 12.26 & 0.353 & 0.104 \\
\hline Total feed cost, on/head & $2,884,606$ & $2,768,864$ & $2,937,670$ & $2,811,110$ & $2,949,566$ & - & - \\
\hline Feed cost, won $/ \mathrm{kg}$ gain $/$ head & 6,033 & 5,232 & 5,709 & 5,577 & 5,623 & - & - \\
\hline $\begin{array}{l}\text { Feed cost relative to control, } \\
\text { won } / \mathrm{kg} \text { gain } / \text { head }\end{array}$ & 0 & -801 & -324 & -456 & -410 & - & - \\
\hline
\end{tabular}

Table 6. Slaughter characteristics and grade of Hanwoo steers as influenced by feeding the whole crop silage based TMR

\begin{tabular}{|c|c|c|c|c|c|c|c|}
\hline \multirow{2}{*}{ Items } & \multicolumn{5}{|c|}{ Experimental diet ${ }^{1)}$} & \multirow{2}{*}{$\mathrm{SEM}^{2)}$} & \multirow{2}{*}{$\operatorname{Pr}<\mathrm{F}^{3)}$} \\
\hline & Control & BS-TMR I & BS-TMR II & RS-TMR I & RS-TMR II & & \\
\hline Slaughter weight, $\mathrm{kg}$ & $660.9^{b}$ & $705.9^{\mathrm{a}}$ & $698.3^{\mathrm{ab}}$ & $698.8^{\mathrm{ab}}$ & $708.9^{\mathrm{a}}$ & 47.15 & 0.0006 \\
\hline Cold carcass weight, $\mathrm{kg}$ & $397.3^{\mathrm{b}}$ & $426.8^{\mathrm{a}}$ & $425.5^{\mathrm{a}}$ & $423.9^{\mathrm{a}}$ & $427.1^{\mathrm{a}}$ & 31.40 & 0.001 \\
\hline Back fat thickness, mm & 10.75 & 13.81 & 12.38 & 13.69 & 13.38 & 3.892 & 0.153 \\
\hline Longissimus dorsi muscle area, $\mathrm{cm}^{2}$ & 89.75 & 90.56 & 90.63 & 90.50 & 92.56 & 8.346 & 0.855 \\
\hline Marbling score & 5.81 & 4.75 & 4.75 & 5.44 & 5.81 & 1.976 & 0.328 \\
\hline Yield index & $66.83^{\mathrm{a}}$ & $64.32^{\mathrm{b}}$ & $65.10^{\mathrm{ab}}$ & $64.32^{\mathrm{b}}$ & $64.32^{\mathrm{b}}$ & 2.702 & 0.047 \\
\hline Quality grade $:\left(1^{++}: 1^{+}: 1: 2\right)$ & $3: 6: 4: 3$ & $2: 3: 8: 3$ & $1: 5: 6: 4$ & $1: 8: 4: 3$ & $3: 6: 5: 2$ & - & - \\
\hline Yield grade : $(\mathrm{A}: \mathrm{B}: \mathrm{C})$ & $5: 11: 0$ & $2: 10: 4$ & $2: 13: 1$ & $3: 9: 4$ & 3:9:4 & - & - \\
\hline
\end{tabular}

${ }^{1)}$ Control, conventional separate feeding of concentrate and rice straw; BS-TMR, whole crop barley silage based TMR; RS-TMR, whole crop rye silage based TMR. The Hanwoo steers were fed BS-TMR I and RS-TMR I up to middle fattening stage, and were fed the diet same as control during late fattening stage.

2) Standard error of the means.

${ }^{3)}$ Probability level. 
것으로 나타났다. 냉도체중에서도 절식체중에서와 비슷하게 나타나 대조구에 비해 도체중이 현저히 $(\mathrm{P}<0.001)$ 큰 것으로 조사되었는 데, 이는 Table 5에서 보는 바와 같이 급여한 시험사료에 따른 증 체 경향이 그대로 반영되어 나타난 결과라 할 수 있다. 등지방 두 께 및 배최장근 면적 역시 대조구에 비해 사일리지 TMR을 섭취
한 한우 거세우에서 높은 경향을 보였으나 큰 차이는 보이지 않았 다. 그러나 근내지방도의 경우 청보리 사일리지 $\mathrm{TMR}$ 을 섭취한 한 우 거세우가 대조구 사료를 섭취한 소에 비해 다소 낮았으며, 평균 육량지수에서 사일리지 TMR을 섭취한 소에 비해 대조구의 소에서 더 높은 $(\mathrm{P}<0.047)$ 것으로 나타났다. 이에 따라 대조구의 소가 사

Table 7. Chemical composition of longissimus dorsi muscle in Hanwoo steers as influenced by feeding the whole crop silage based TMR

\begin{tabular}{|c|c|c|c|c|c|c|c|}
\hline \multirow{2}{*}{ Items } & \multicolumn{5}{|c|}{ Experimental diets ${ }^{1)}$} & \multirow{2}{*}{$\mathrm{SEM}^{2)}$} & \multirow{2}{*}{$\operatorname{Pr}<F^{3}$} \\
\hline & Control & BS-TMR I & BS-TMR II & RS-TMR I & RS-TMR II & & \\
\hline Examined number, head & 7 & 9 & 7 & 8 & 7 & & \\
\hline \multicolumn{8}{|c|}{ Composition ( $\%$, fresh basis) } \\
\hline Moisture & 61.44 & 62.90 & 63.90 & 61.46 & 61.18 & 3.721 & 0.558 \\
\hline $\mathrm{CP}$ & 56.32 & 58.27 & 58.34 & 58.02 & 58.60 & 2.125 & 0.752 \\
\hline $\mathrm{EE}$ & 40.61 & 39.33 & 38.89 & 39.47 & 39.05 & 1.356 & 0.108 \\
\hline Ash & 2.05 & 2.37 & 2.74 & 2.50 & 2.32 & 0.051 & 0.788 \\
\hline
\end{tabular}

${ }^{1)}$ Control, conventional separate feeding of concentrate and rice straw; BS-TMR, whole crop barley silage based TMR; RS-TMR, whole crop rye silage based TMR. The Hanwoo steers were fed BS-TMR I and RS-TMR I up to middle fattening stage, and were fed the diet same as control during late fattening stage.

2) Standard error of the means. ${ }^{3)}$ Probability level.

Table 8. Quality characteristics of longissimus dorsi muscle in Hanwoo steers as influenced by feeding the whole crop silage based TMR

\begin{tabular}{|c|c|c|c|c|c|c|c|}
\hline \multirow{2}{*}{ Items } & \multicolumn{5}{|c|}{ Experimental diets ${ }^{1)}$} & \multirow{2}{*}{$\mathrm{SEM}^{2)}$} & \multirow{2}{*}{$\operatorname{Pr}<\mathrm{F}^{3)}$} \\
\hline & Control & BS-TMR I & BS-TMR II & RS-TMR I & RS-TMR II & & \\
\hline Water holding capacity, \% & 52.89 & 53.92 & 54.61 & 51.31 & 48.78 & 5.186 & 0.235 \\
\hline Drip loss, $\%$ & 3.28 & 3.60 & 3.53 & 4.07 & 3.70 & 1.146 & 0.767 \\
\hline Cooking loss, $\%$ & 22.53 & 24.69 & 25.57 & 24.63 & 23.17 & 2.593 & 0.221 \\
\hline $\mathrm{pH}$ & 5.39 & 5.42 & 5.40 & 5.39 & 5.38 & 0.036 & 0.455 \\
\hline Shear force, $\left(\mathrm{kg} / \mathrm{cm}^{2}\right)$ & $2131^{\mathrm{b}}$ & $2392^{\mathrm{a}}$ & $2190^{\mathrm{ab}}$ & $2193^{\mathrm{ab}}$ & $2390^{\mathrm{ab}}$ & 418.8 & 0.046 \\
\hline
\end{tabular}

${ }^{1)}$ Control, conventional separate feeding of concentrate and rice straw; BS-TMR, whole crop barley silage based TMR; RS-TMR, whole crop rye silage based TMR. The Hanwoo steers were fed BS-TMR I and RS-TMR I up to middle fattening stage, and were fed the diet same as control during late fattening stage.

2) Standard error of the means. ${ }^{3)}$ Probability level.

Table 9. Meat color of longissimus dorsi in Hanwoo steers as influenced by feeding the whole crop silage based TMR

\begin{tabular}{|c|c|c|c|c|c|c|c|}
\hline \multirow{2}{*}{ Items ${ }^{1)}$} & \multicolumn{5}{|c|}{ Experimental diets ${ }^{2)}$} & \multirow{2}{*}{$\mathrm{SEM}^{3)}$} & \multirow{2}{*}{$\operatorname{Pr}<F^{4)}$} \\
\hline & Control & BS-TMR I & BS-TMR II & RS-TMR I & RS-TMR II & & \\
\hline Hunter L & 38.78 & 40.73 & 40.38 & 42.10 & 39.31 & 3.395 & 0.399 \\
\hline Hunter a & 17.86 & 19.22 & 19.92 & 18.78 & 19.25 & 1.594 & 0.235 \\
\hline Hunter $b$ & 9.87 & 10.99 & 10.40 & 10.34 & 10.64 & 1.234 & 0.524 \\
\hline
\end{tabular}

\footnotetext{
${ }^{1)} \mathrm{L}:$ lightness, $\mathrm{a}:$ redness, $\mathrm{b}:$ yellowness

${ }^{2)}$ Control, conventional separate feeding of concentrate and rice straw; BS-TMR, whole crop barley silage based TMR; RS-TMR, whole crop rye silage based TMR. The Hanwoo steers were fed BS-TMR I and RS-TMR I up to middle fattening stage, and were fed the diet same as control during late fattening stage.

${ }^{3)}$ Standard error of the means. ${ }^{4)}$ Probability level.
} 
일리지 TMR을 섭취한 소에 비하여 육량 A 등급에서 더 많은 두 수를 보였다. 그러나 육질 1 등급 이상의 경우 시험사료에 따른 차 이는 없는 것으로 나타났다.

\section{4. 배최장근의 이화학적 특성}

각 처리별로 7두 9두를 대상으로 조사한 바, 시험사료 급여에 따른 한우 배최장근(longissimus dorsi muscle) 의 수분, 조단백 질, 조지방 및 조회분 함량은 섭취한 사료에 의한 영향을 받지 않 은 것으로 나타났다(Table 7). 배최장근의 보수력, Drip loss, 가 열감량, $\mathrm{pH}$ 및 전단력은 Table 8에서와 같다. 즉, 보수력의 경우 다른 처리에 비해 RS-TMR II의 소에서 다소 낮았으며, 육즙 손실 (drip loss)과 가열감량은 대조구의 한우에서 다소 낮은 경향을 보 였으나 시험사료 간 큰 차이를 보이지는 않았다. 또한 배최장근의 $\mathrm{pH}$ 는 시험사료에 의한 영향을 받지 않은 반면 전단력은 사일리지 $\mathrm{TMR}$ 을 섭취한 한우에 비해 관행사양 방법으로 비육된 한우(대조
구)에서 낮았으나 $(<0.046)$ 사일리지 $\mathrm{TMR}$ 을 섭취한 처리구 간에 는 차이가 없었다.

배최장근의 밝음 정도와 적색도 그리고 황색도를 측정한 바, 조 사된 항목 모두가 대조구의 한우가 다소 낮은 경향을 보였으며, 사 일리지 TMR 처리구 간에는 비슷한 경향을 보였다(Table 9).

\section{5. 배최장근의 지방산 조성}

한우 거세우 배최장근 지방의 모든 지방산 조성은 시험사료 섭취 에 의한 영향을 받지 않은 것으로 나타났다 (Table 10). 예상된 바 와 같이 oleic acid의 조성 비율이 $47.23 \sim 48.91 \%$ 의 범위로서 가 장 큰 비율을 보였으며, 그 다음으로는 palmitic acid(26.24 $29.68 \%)$ 와 stearic $\operatorname{acid}(9.89 \sim 11.20 \%)$ 의 비율을 보였다. 전체 지 방산에서 포화지방산(saturated fatty acid, SFA)가 차지하는 비율 이 모든 처리에서 $40.21 \sim 42.52 \%$ 였으며 불포화지방산 (unsaturated fatty acid, USA)의 비율은 $56.53 \sim 59.01 \%$ 인 것으로 조사되었다.

Table 10. Fatty acid composition of longissimus dorsi in Hanwoo steers as influenced by feeding the whole crop silage based TMR

\begin{tabular}{|c|c|c|c|c|c|c|c|}
\hline \multirow{2}{*}{ Fatty acids } & \multicolumn{5}{|c|}{ Experimental diets ${ }^{1}$} & \multirow{2}{*}{ SEM $^{2)}$} & \multirow{2}{*}{$\operatorname{Pr}>F^{3)}$} \\
\hline & Control & BS-TMR I & BS-TMR II & RS-TMR I & RS-TMR II & & \\
\hline C14:0 & 3.45 & 3.32 & 3.28 & 3.39 & 3.11 & 0.071 & 0.864 \\
\hline C14:1 & 1.21 & 1.21 & 1.06 & 1.2391 & 0.98 & 0.047 & 0.613 \\
\hline C16:0 & 26.36 & 27.10 & 29.68 & 26.24 & 27.62 & 0.259 & 0.392 \\
\hline C16:1 & 5.40 & 5.48 & 5.18 & 5.39 & 5.12 & 0.106 & 0.819 \\
\hline C18:0 & 9.89 & 10.11 & 11.20 & 10.57 & 11.13 & 0.150 & 0.061 \\
\hline C18:1 & 48.91 & 48.49 & 47.23 & 48.88 & 48.10 & 0.348 & 0.751 \\
\hline C18:2 & 2.25 & 2.32 & 1.86 & 2.34 & 2.41 & 0.914 & 0.268 \\
\hline C18:3 & 0.37 & 0.33 & 0.35 & 0.39 & 0.40 & 0.021 & 0.821 \\
\hline C20:1 & 0.08 & 0.09 & 0.09 & 0.09 & 0.09 & 0.004 & 0.413 \\
\hline C20:4 & 0.18 & 0.21 & 0.20 & 0.18 & 0.17 & 0.010 & 0.860 \\
\hline $\mathrm{C} 22: 1$ & 0.15 & 0.24 & 0.29 & 0.21 & 0.25 & 0.018 & 0.198 \\
\hline $\mathrm{C} 24: 1$ & 0.09 & 0.09 & 0.10 & 0.08 & 0.08 & 0.004 & 0.689 \\
\hline Others & 0.09 & 0.61 & 0.53 & 0.61 & 0.44 & 0.070 & 0.387 \\
\hline $\mathrm{SFA}^{4)}$ & 40.21 & 40.93 & 42.52 & 40.59 & 41.84 & 0.328 & 0.257 \\
\hline UFA $^{5)}$ & 58.97 & 58.66 & 56.53 & 59.01 & 57.72 & 0.319 & 0.193 \\
\hline MUFA $^{6)}$ & 56.08 & 55.73 & 54.04 & 56.01 & 54.70 & 0.312 & 0.357 \\
\hline UFA/SFA & 1.48 & 1.44 & 1.34 & 1.46 & 1.38 & 0.019 & 0.262 \\
\hline MUFA/SFA & 1.40 & 1.37 & 1.28 & 1.39 & 1.31 & 0.018 & 0.322 \\
\hline
\end{tabular}

${ }^{1)}$ Control, conventional separate feeding of concentrate and rice straw; BS-TMR, whole crop barley silage based TMR; RS-TMR, whole crop rye silage based TMR. The Hanwoo steers were fed BS-TMR I and RS-TMR I up to middle fattening stage, and were fed the diet same as control during late fattening stage.

2) Standard error of the means. ${ }^{3)}$ Probability level. ${ }^{4)}$ SFA, saturated fatty acid. ${ }^{5)}$ UFA, unsaturated fatty acid.

6) MUFA, mono-unsaturated fatty acid. 
또한 불포화지방산 중 단일불포화지방산 (monounsaturated fatty acid, MUFA)의 비율은 54.04 56.08\%의 범위였다. 조사된 한우 거세우에서의 포화지방산에 대한 불포화지방산의 비율 (UFA/SFA) 은 $1.38 \sim 1.48$ 범위로 나타나으며, 포화지방산에 대한 단일불포화 지방산 비율 $(\mathrm{MUFA} / \mathrm{SFA})$ 은 $1.28 \sim 1.40$ 의 범위인 것으로 조사되 었다.

\section{고 찰}

2000년대에 들어 국내에서도 TMR을 한우용 사료로 이용하기 위한 연구가 시작되었다. 일찍이 조 등 (2000)은 거세 한우 송아지 40 두를 대상으로 총체보리 담근먹이가 거세 한우의 성장과 사료이 용성에 미치는 효과를 조사한 바, 증체량과 사료 이용효율 등에서 기존의 사료 관행 급여구에 비해 개선된 효과를 보였다고 보고하였 다. 이밖에도 면양(이 등, 2002)과 흑염소(황 등, 2008)에 의해 각각 청예사료작물과 청보리 사일리지의 사료적 가치가 조사되어 사료 이용성 측면에서 긍정적인 결과가 있었음이 발표되기도 했다. 이밖에도 김 등 (2003)이 섬유질 배합사료 급여가 비육 후기의 거 세한우를 대상으로 반추위 내 발효성상과 소화율 및 산육성에 미치 는 효과 등이 조사된 바, 반추위 내 발효여건 및 성장과 육질등급 등이 개선된 효과를 보였다고 보고한 바 있으며, 이러한 효과는 이 등 (2003)에 의해서도 확인되었다. 조 등 (2009)도 거세한우에 섬유 질배합사료를 급여한 바, 배합사료 중심의 사료 급여에 비해 생산 성과 도체특성에서 개선되었으며, 생산비 절감효과도 있었음을 보 고하였다. 이렇듯 건초를 이용한 TMR 급여효과가 주종을 이루었 으나 정부에 의해 총체보리 (청보리) 생산 및 이용이 권장되자 청보 리 사일리지의 사료적 가치가 조사되기 시작했다. 그러나 본 시험 에서와 같이 청보리 사일리지 또는 청호밀 사일리지를 이용한 습 $\mathrm{TMR}$ 급여효과를 배합사료와 볏짚 중심의 관행적인 급여방법과 비 교하거나 TMR 급여기간에 따른 증체와 각종 도체 성적 및 사료 비를 조사한 시험은 거의 없다.

일반적으로 가축의 생산성은 사료 섭취량에 의해 영향을 받는 것 으로 알려지는데, 본 시험에서의 한우 증체량 역시 전체적으로 사 료섭취량에 의한 영향을 받은 것으로 나타났다. 전체 성장단계 중 육성기와 비육전기 및 비육중기에서 관행사양구 (농후사료와 볏짚 을 계획에 따라 정해진 량 급여)의 한우에 비해 대부분 사일리지 $\mathrm{TMR}$ 처리구의 한우에서 섭취량과 증체량이 다소 높았으나 비육후 기에서는 반대의 경향을 보였다 (Table 3). 그러나 TMR 급여구의 한우에 비해 관행사양구에서 비육중기까지 사료섭취량 저하로 둔화 된 증체가 비육후기에 들어 사일리지 $\mathrm{TMR}$ 의 섭취량 증가에 따라 크게 개선됨으로서 보상 성장효과를 보인 것으로 여겨진다. 또한 비육중기까지 청보리 사일리지 TMR을 섭취한 한우(RS-TMR I) 및 청호밀 사일리지 $\mathrm{TMR}$ 을 섭취한 한우(RS-TMR I)에게 비육 후기에 관행사료구와 동일한 사료를 급여했을 때 건물 섭취량은 여 전히 전체 사양기간에 걸쳐 사일리지 $\mathrm{TMR}$ 을 급여한 처리구 (BS-TMR II 및 RS-TMR II)에 비해 다소 낮았으나 그 기간에서
의 증체량에서는 사료섭취량에 따른 뚜렷한 경향을 보이지는 않았 다 (Table 3). 전체 성장단계별 한우 사양시험에 이용된 시험사료 의 체내 이용성이 조사되지는 못했다 그러나 Qin 등 (2010)이 비 육 중기의 사양시험에서와 동일한 사료와 급여 기준을 적용한 대사 시험을 실한 결과 반추위 내 건물 및 조단백질의 유효 분해율에서 는 청호밀 사일리지 TMR이 관행사료와 청보리 사일리지 TMR 보다 더 높았으나 관행사료와 청보리 TMR 간에는 차이가 없었다. 그러나 $\mathrm{NDF}$ 의 유효 분해율에서는 두 종류의 $\mathrm{TMR}$ 이 관행사료보 다 현저히 증가된 것을 알 수 있었다. 이러한 경향은 시험사료의 전장소화율에서도 동일한 것으로 나타났는데, 이러한 결과로 보아 적어도 소 체내에서의 영양소 이용율에서는 본 시험에서 이용한 사 일리지 TMR이 배합사료와 볏짚을 급여한 관행사료에 못지 않았으 며, 특히 청보리 사일리지에 비해 청호밀 사일리지의 체내 이용 효 율이 더 높은 것으로 나타났다. 일반적으로 볏짚의 사료적 가치가 건초(조 등, 2009)나 사료작물 (지 등, 2010)에 비해 낮기 때문에 시험사료의 체내 이용율을 조사료 자원 중심으로 비교할 수는 없 다. 그러나 본 시험에서 한우에 급여한 $\mathrm{TMR}$ 의 조단백질 및 $\mathrm{TDN}$ 함량이 관행사양구의 농후사료에 비해 다소 낮음에도 불구하고 증 체량에서 다소 개선된 점은 비육중기까지 TMR 급여구에서 상대적 으로 건물섭취량과 $\mathrm{TDN}$ 섭취량이 증가된 때문으로 여겨진다. 아 울러 동일한 시험사료의 소 체내 이용율 (Qin et al., 2010)에서 조 사된 바와 같이 사일리지 $\mathrm{TMR}$ 의 체내 이용율이 관행사양구의 시 험사료에 비해 더 높았기 때문인 점도 영향한 것으로 여겨진다. 또 한 본 시험에서 전체 사양기간에 걸쳐 청보리 사일리지 TMR (BS-TMR II)에 비하여 청호밀 사일리지 TMR(RS-TMR II)을 섭취한 한우의 총 증체량이 다소 높았던 결과(Table 5) 역시 Qin 등(2010) 조사한 대사시험의 결과와 무관하지 않은 것으로 보인다.

사료비 (Table 4)의 경우 육성기에서는 관행사료의 건물 $\mathrm{kg}$ 당 사료비가 TMR에 비해 다소 높았으나 비육전기 및 비육후기에서는 관행사양구에 비해 TMR 급여구의 사료비가 더 높았다. 그러나 비 육후기의 경우 이러한 경향이 반전되어 관행사양구의 사료비가 더 크게 소요되었다. 전체 사양기간 동안의 사료비 (Table 5)에서는 관행사료비 $(2,884,606$ 원)에 비해 BS-TMR II 및 RS-TMR II 처 리구의 사료비가 다소 많이 소요되었으나 두당 $\mathrm{kg}$ 증체 당 사료비 는 관행사양구에 비해 최소 324원 (BS-TMR II)이 적게 소요되었 으며 최대 801원(BS-TMR I)이 더 적게 소요된 것으로 나타났다. 사료비에서의 차이는 사료단가에 의해서 라기 보다는 대부분 섭취 량에 의한 영향을 받은 것으로 보인다. 비육전기, 비육중기 및 비 육후기의 건물섭취량이 그 예가 된다(Table 4). 그러나 본 시험을 위해 제공된 $\mathrm{TMR}$ 의 공급가가 일반 한우사육농가에 공급하는 가격 이므로 한우사육농가에서 직접 자가 $\mathrm{TMR}$ 을 조제할 경우 더 큰 사료비의 절감이 가능할 것으로 여겨진다. 조 등 (2008)이 거세한 우를 대상으로 섬유질배합사료를 급여하고 관행사료 급여 시와 비 교한 결과 생산비 절감효과가 있음을 보고한 바 있어 부분적으로 본 연구 결과를 뒷받침해주었다. 그러나 본 연구에서와 같이 육성 기에서 비육후기까지 일관적으로 사료작물 사일리지 TMR을 급여 
하고 증체와 사료비를 관행사양 방법과 비교한 결과가 보고되지 않 았기에 한우 생산비 중 사료비 측면에서 본 시험에서의 결과와 비 교하기는 어렵다.

본 시험에 이용된 총 80 두의 도체특성 및 육질과 육량 등급 판 정 결과(Table 6), 생체중(절식체중)과 냉도체중, 그리고 등지방두 께 및 등심면적은 사양시험의 총 증체량(Table 5)과 비슷한 경향 을 보여 사일리지 TMR을 섭취한 한우 거세우에서 다소 높은 반 면 근내지방도의 경우 청보리 사일리지 TMR을 섭취한 한우에서 관행사양구에 비하여 다소 낮았지만 BS-TMR II 처리구를 제외하 고는 1 등급 이상 출현율이 $81 \%$ 이상으로 시험사료 간 거의 차이 가 없었다 (Table 6). 이와는 반대로 육량지수 및 육량등급은 관행 사양구의 한우에서 다소 높은 경향을 보였는데, 이는 Table 3에서 보는 바와 같이 비육후기 동안 대조구 한우의 건물 및 $\mathrm{TDN}$ 섭취 량을 제외하고는 비육 중기까지 건물과 $\mathrm{TDN}$ 섭취량이 $\mathrm{TMR}$ 급여 구에 비해 낮아 체지방 합성을 위한 에너지 섭취량이 부족한 때문 (한우컨설팅지침서, 2009)으로 여겨진다. 이화학적 특성 (Table 8) 중 전단력은 관행사료 급여구에 비해 사일리지 TMR 급여구의 한 우에서 다소 높은 경향을 보였으나, 배최장근의 밝기에서는 전체적 으로 처리 간 거의 차이가 없었다. 현재까지 TMR, 특히 사일리지 $\mathrm{TMR}$ 과 배최장근의 이화학적 특성 및 밝기 측면에서 관행사료와 비교한 결과가 보고된 바 없어 본 시험 결과를 비교하기는 어렵다. 그러나 홍 등 (1996)은 거세한우 송아지를 대상으로 480일간 배합 사료를 공통으로 급여하고 볏짚과 3종류의 담근먹이(옥수수, 청호 밀 및 이탈리안 라이그라스)를 자유채식토록 한 후 도체특성에서 조사료 종류에 의한 차이를 조사한 바, 볏짚 급여에 비해 담근먹이 급여로 도체 지방과 등지방두께가 다소 증가된 반면 육색과 지방색 및 배최장근 단면적과 육량지수를 다소 낮춘 것으로 보고하였다. 또한 본 시험에서는 거세 한우의 배최장근 내 지방의 지방산 조성 이 시험사료 및 TMR 급여기간에 영향을 받지 않았으며, 배최장근 의 oleic acid 함량은 47.23 48.91\%의 범위를 나타냄으로써 사 일리지 TMR이 배합사료 급여에 비해 부정적인 영향을 미친 것으 로 보이지는 않는다. 본 시험의 30 개월령 거세한우로부터 조사된 oleic acid 함량은 송 등 (2000)이 조사한 25개월령의 한우 거세우 배최장근 지방의 평균 oleic acid 함량인 $44 \%$ 와 Wang 등(2006) 이 조사한 26개월령의 한우 거세우 배최장근의 평균 oleic acid 함 량인 $46 \%$ 보다 다소 높은 수준이었다. 그러나 이전에 보고된 결과 와 본 시험에서의 결과만으로 미루어 볼 때 거세 한우의 연령 증가 에 따라 oleic acid 함량이 증가될 가능성이 있는 것으로 추정되지 만 추후 연구를 통한 확인이 필요한 것으로 여겨진다.

본 시험은 국내에서 생산되는 동계사료작물(청보리 및 청호밀)을 사일리지 형태로 조제된 한우용 TMR과 한우사육 농가에서 관행적 으로 급여하는 방법 (배합사료와 볏짚의 분리 급여)이 증체와 사료 비 및 도체특성에 미치는 효과를 비교하고자 거세한우를 대상으로 육성기에서 비육후기에 걸쳐 실시되었다. 조사된 시험 결과로 미루 어 보아 배합사료와 볏짚 중심의 관행사양방법에 비하여 동계사료 작물 사일리지를 이용한 TMR 급여가 거세한우의 육질에 크게 영
향하지 않은 반면 증체를 개선하고 사료비를 절감할 수 있을 것으 로 보인다. 이러한 결과는 향후 양질의 국내산 사일리지 TMR을 한우에 적용할 경우 높은 한우 생산비를 낮출 수 있는 방법이 될 수 있을 것으로 보이며, 청보리나 청호밀 등 동계사료작물의 수요 증가로 이어질 것으로 예상된다. 단, 비육기에서 사일리지 TMR의 에너지 $(\mathrm{TDN})$ 함량을 높여 지방교잡도를 개선시킬 전략이 필요한 것으로 여겨진다. 아울러 청보리 및 청호밀 사일리지 $\mathrm{TMR}$ 의 사료 적 가치는 거의 비슷한 것으로 보인다.

\section{요 약}

본 연구는 주요 동계사료작물인 청보리와 청호밀을 이용한 TMR 급여가 한우 거세우의 생산성과 사료비, 그리고 도체특성과 등급판 정 및 배최장근의 이화학적 특성에 미치는 효과를 조사하기 위해 한우 거세우 송아지 80 두를 대상으로 육성기에서 비육후기까지 총 680 일에 걸쳐 실시되었다. 시험사료는 배합사료와 볏짚을 분리 급 여하는 관행사양구 (Control), 청보리 사일리지 TMR을 비육 중기 까지 자유채식토록 하고 비육 후기에는 관행사양구와 동일한 사료 를 급여하는 처리구(BS-TMR I), 청보리 사일리지 TMR을 비육 후기까지 자유채식토록 하는 처리구 (BS-TMR II), 청호밀 사일리 지 TMR을 비육 중기까지 자유채식토록 하고 비육 후기에는 관행 사양구와 동일한 사료를 급여하는 처리구 (RS-TMR I), 청호밀 사 일리지 TMR을 비육 후기까지 자유채식토록 하는 처리구 $(\mathrm{RS}-$ $\mathrm{TMR}$ II)로 구성하였다. 각 처리 당 거세된 송아지 16 두 씩을 배 치하였고, 처리 당 거세한우 송아지를 4두씩 4개의 pen에 수용하 였으며, 완전임의배치 방법으로 각 처리구의 pen을 배치하였다. 한 우 거세우의 증체량은 관행사양구에 비해 육성기 및 비육전기에서 청보리 및 청호밀 사일리지 $\mathrm{TMR}$ 을 섭취한 처리구에서 다소 높았 고 비육 중기에서 현저히 높았으나 $(\mathrm{P}<0.0001)$ 비육 후기에서는 RS-TMR II를 제외하고는 관행사양구의 한우에서 다소 높은 것으 로 나타났다. 한우 두당 $\mathrm{kg}$ 증체 당 사료비는 관행사양구의 한우에 비해 청보리 및 청호밀 사일리지 $\mathrm{TMR}$ 을 섭취한 한우에서 다소 낮았다. 또한 비육 후기까지 사일리지 $\mathrm{TMR}$ 을 섭취한 처리구 (BS-TMR II 및 RS-TMR II)에 비하여 비육 중기까지 사일리지 $\mathrm{TMR}$ 을 섭취하고 비육 후기에는 관행사료를 섭취한 처리구(BSTMR I 및 RS-TMR I)에서 두당 $\mathrm{kg}$ 증체 당 사료비가 다소 감소 되었다. 사일리지 TMR이 관행사료 급여에 비해 한우 거세우의 도 체중, 등지방 두께 및 배최장근 면적을 다소 증가시켰으나 육량지 수를 낮추었다 $(\mathrm{P}<0.047)$. 다른 시험사료에 비해 청보리 사일리지 $\mathrm{TMR}$ 이 근내지방도를 다소 낮추었으나 육질 1 등급 이상 출현두수 에는 처리 간 차이가 없었다. 한우 거세우 내 배최장근의 화학적 성분, 도체특성, 대부분의 육질 특성, 육색 및 지방산 조성은 시험 사료에 의한 영향을 받지 않았다. 그러나 전단력은 사일리지 TMR 을 섭취한 한우에 비해 관행사양 방법으로 비육된 한우에서 낮았으 나 $(\mathrm{P}<0.046)$ 사일리지 $\mathrm{TMR}$ 을 섭취한 처리구 간에는 차이가 없었 다. 본 시험의 결과로 미루어 보아 배합사료와 볏짚 중심의 관행사 
양방법에 비하여 $\mathrm{BS}$ 또는 $\mathrm{RS}$ 를 이용한 $\mathrm{TMR}$ 급여가 거세한우의 육질에 크게 영향하지 않은 반면 증체를 개선하고 사료비를 절감할 수 있을 것이라 여겨진다. 또한 전체적으로는 청보리 및 청호밀 사 일리지 $\mathrm{TMR}$ 의 사료적 가치는 거의 비슷한 것으로 여겨진다. (주제어: 한우 거세우, 사일리지 TMR, 증체, 사료비, 도체 특성)

\section{사 사}

이 논문은 2008년도 농림수산식품기술기획평가원의 기획과제(청 보리와 호밀 사일리지 TMR을 이용한 한우 및 낙농 사양 프로그 램 개발) 사업의 연구비 지원에 의해 연구되었다.

\section{인 용 문 헌}

AOAC. 1995. Official Methods of Analysis(16th ed.). Association of Official Analycal Chemists, Washington, D.C.

Folch, J., Less, M. and Sloane-Stanley, G. H. 1957. A simple method for isolation and purification of total lipids from animal tissues. J. Biol. Chem. 226:497-509.

Qin, W. Z., Jin, G.L., Kim, J. K., Oh, Y. K., Leem S. C. and Song, M. K. 2010. Estimation of availability of whole crop barley and rye silage TMR in the cattle. J. Kor. Grassl. Forage Sci. 30:343-354.

SAS. 2002. SAS Procedures Guide release 9.0 SAS institute Inc. Cary, NC. U.S.

Shinekhuu, J., Jin, G. L., Ji, B. J., Li, X. Z., Oh, Y. K., Hong, S. K. and Song, M. K. 2010. Protein fractionation of whole crop silages, and effect of borate-phosphate buffer extraction on in vitro fermentation characteristics, gas production and degradation. Kor. J. Anim. Sci \& Technol. 51:369-378.

Steel, R. G. D. and Torrie, J. H. 1980. Principles and procedures of statistics. Mcgraw Hill Book Co., NY.

Van Soest, P. J., Robertson J. B. and Lewis, B. A. 1991. Methods for fiber, neutral detergent fiber, and non starch polysaccharides in relation to animal nutrition. J. Dairy Sci. 74:3583-3597.

Wang, J. H., Choi, S. H., Lim, K. W., Kim, K. H. and Song, M. K. 2006. Effect of the mixed oil and monensin supplementation, and feeding duration of supplements on c9,t11-CLA contents in plasma and fat tissues of Korean native (Hanwoo) steers.
Asian-Austr. J. Anim. Sci. 19:1464-1469.

Wheeler, T. L., Shackelford, S. D. and Koohmaraie, M. 2000. Relationship of beef longissimus tenderness classes to tenderness of gluteus medius, semimembranosus and biceps femoris. J. Anim. Sci. 78: 2856-2861.

김경훈, 김기수, 이상철, 오영균, 정찬성, 김건중. 2003. 섬유질배합사료 급 여가 비육후기 거세한우의 반추위 발효성상, 소화율 및 산육성에 미치 는 영향. 한국동물자원과학회지 45:387-396.

맹원제, 이광전, 정태영, 정길생, 김동균, 손봉환. 1989. 유우생산학. 향문사. 송만강, 김내수, 정정수, 최양일, 원유석, 정재경, 최성호. 2000. 농후사료 급여수준이 거세 한우의 증체와 부위별 지방조직의 지방산 조성에 미 치는 효과. 한국축산학회지 42:859-870.

이덕윤, 고종열, 최낙진, 이상석, 송재용, 이세영, 박성호, 성하균, 하종규. 2003. 유형별 완전혼합사료 급여가 반추위내의 발효성상 및 영양소 소 화율에 미치는 영향. 한국동물자원과학회지. 45:805-812.

이현준, 조광근, 김원호, 김현섭, 김준식, 강승하, 강상기, 우정희. 2002. 청 예사료작물과 볏짚을 이용한 완전배합발효사료의 제조와 영양적 가치. 한국동물자원과학회지 44:75-86.

조영무, 권응기, 장선식, 김태일, 박병기, 강수원, 백봉현. 2008. 섬유질배합 사료 급여가 거세한우의 발육 및 도체특성에 미치는 영향. 한국동물 자원과학회지 50:363-372.

조원모, 조영무, 홍성구, 정의수, 이종문, 윤상기. 2000. 보리 총체담근먹이 급여가 거세한우의 발육, 사료이용성 및 육질에 미치는 영향. 한국동 물자원과학회지 42:181-188.

조원모, 장선식, 조영무, 김형철, 권응기, 양승학, 백봉현. 2009. 조사료원과 출하시기가 거세한우의 발육과 도체특성에 미치는 영향. 한국초지조사 료지 29:375-382.

지병주, 김광림, J. Shinekhuu, W. Quin, 오영균, 손용석, 서성, 송만강. 2010. 소에 의한 다양한 사일리지의 이용율 및 TDN 평가. 한국초지 조사료지 30:169-178.

한국사양표준, 한우. 2007. 농촌진흥청 축산과학원. 한우컨설팅지침서. 2009. 한우자조금관리위원회.

황경준, 고서봉, 박형수, 박남건, 고문석, 정하연, 김문철, 송상택, 김대운. 2008. 이탈리안 라이그라스, 귀리의 혼파 비율, 예취 횟수가 사초 생

산성 및 사료가치에 미치는 영향. 한국초지조사료지 28:295-300.

홍성구, 이병석, 강희설, 조원모, 이종문, 백봉현, 김내수, 송만강. 1996. 담근먹이 급여가 거세한우의 도체특성에 미치는 효과. 한국축산학회지. 38:69-76.

(Received Feb. 14, 2012; Revised Mar. 28, 2012; Accepted Apr. 19, 2012) 